\title{
ВІК СЕКСУАЛЬНОӤ ЗГОДИ ТА ПРОБЛЕМИ ВРЕГУЛЮВАННЯ ДОБРОВІЛЬНИХ СТАТЕВИХ ВІДНОСИН МІЖ НЕПОВНОЛІТНІМИ ЗА КРИМІНАЛЬНИМ ЗАКОНОДАВСТВОМ УКРАЇНИ
}

\section{ФУРСА Вадим Вікторович - викладач кафедри тактико-спеціальної підготовки Дніпропетровського державного університету внутрішніх справ \\ DOI:10.32782/EP.2020.2.20 \\ УДК 343.54}

У статті, на основі аналізу теоретичних напрацювань з кримінального права та діючих положень Розділу IV Особливої иастини Кримінального кодексу України, здійснено спробу проаналізувати питання віку сексуальної згоди та проблемні питання врегулювання добровільних статевих відносин між неповнолітніми. Зокрема, у статті зазначається, що внаслідок майже одночасної імплементаціӥ у кримінальне законодавство України правових норм, двох не до кіния узгоджених між собою Конвениій законодавцем не врегульовано добровільні статеві відносини між неповнолітніми. Закріплюючи положення про кримінальну відповідальність за добровільні статеві зносини тільки повнолітніх, законодавещь, вносячи зміни у статті 155 та 156 КК Украӥни, також допустився помилки, яка викликає труднощі при врегулюванні статевих відносин між неповнолітніми у вічі 14-18 років. Так, природні чи неприродні статеві зносини між неповнолітніми у віці від 14 до 18 років не визнаватимуться злочином, у той час як будь які сексуальні дї не пов'язані із сексуальним проникненням у тіло такої особи кваліббікуватимуться як злочин, передбачений ст. 156 КК Украӥни.

Намагаючись вирішити питання врегулювання добровільних статевих відносин між неповнолітніми, було проаналізовано кримінальне законодавство деяких країн, яке направлене на врегулювання таких відносини як між неповнолітніми, так $i$ між неповнолітніми та повнолітніми особами. Акцентовано увагу, що законодавиі зарубіжних країн нама- гаються мінімізувати втручання у добровільні статеві відносини неповнолітніх шляхом закріплення у кримінальних нормах вікових чи інших факторів, які дозволяють такі відносини як між неповнолітніми, так $i$ між неповнолітніми та повнолітніми особами, що не досягли певного віку.

Ключові слова: згвалтування, сексуальне насильство, статеві зносини, розбещення неповнолітніх, розпусні дї, примушування до вступу в статевий зв'язок, вік сексуальної згоди, врегулювання статевих відносин, статеві злочини.

\section{Постановка проблеми}

Тема статевих злочинів, а зокрема, статевих злочинів проти неповнолітніх і нині залишається актуальною. Вони становлять підвищену суспільну небезпеку, а положення про те, що дитина внаслідок ï фізичної та розумової незрілості потребує посиленої охорони й піклування, уже давно отримало загальне визнання. Внаслідок вчинення статевого злочину відносно особи, яка не досягла 18 років, нерідко порушується її подальший нормальний фізичний і психічний розвиток. У таких осіб можуть формуватися неправильні, з моральної точки зору, уявлення про статеві стосунки, а згодом не виключена й деформація особистості. Також слід мати на увазі, що статевим злочинам властива висока латентність, тому зареєстровані випадки цієї категорії злочинів не відображають реальної дійсності. 


\section{Кримінальне право, кримінальний процес та криміналістика}

Це значною мірою активізувало пошуки шляхів вдосконалення чинного законодавства в Україні, які відбуваються і донині. Внесені Законом України від 6 грудня 2017 р. «Про внесення змін до кримінального та кримінально-процесуального кодексів України з метою реалізації положень Конвенції Ради Европи про запобігання насильству стосовно жінок і домашньому насильству та боротьбу з цими явищами» та Законом України від 14 березня 2018 «ро внесення змін до Кримінального кодексу України щодо захисту дітей від сексуальних зловживань та сексуальної експлуатації» зміни у Розділ IV КК України, на жаль, утворюють прогалини у законодавстві та потребують нагального вирішення.

\section{Аналіз публікацій, у яких започатковано розв'язання даної проблеми}

Проблеми загальної кримінально-правової та кримінологічної характеристики злочинів проти статевої свободи та статевої недоторканості відображаються у роботах Ю.В. Александрова, Ю.М. Антоняна, М.І. Бажанова, Ю.В. Бауліна, А.П. Брич, В.В. Голіни, О.М. Джужи, О.О. Дудорова, А.П. Ігнатова, М.Й. Коржанського, В.В. Аеня, А.С. Аукаш, М.І. Мельника, В.О. Навроцького, А.В. Савченка, О.В. Синеокого, О.О. Світличного, В.В. Сташиса, В.Я. Тація, С.В. Чмута, I.І. Чугунікова, М.І. Хавронюка, Ю.І. Шевчука, Я.М. Яковлєва та інших. Незважаючи на значні наукові розробки та досягнення юридичної практики у сфері захисту осіб від сексуальних посягань, кардинальні зміни кримінально-правових норм, зазвичай, призводять до втрати актуальності існуючих наукових праць та необхідності знову проводити наукові розробки вже зміненої норми.

\section{Мета статті}

Враховуючи фактично закріплений Законом України від 14 березня 2018 «Про внесення змін до Кримінального кодексу України щодо захисту дітей від сексуальних зловживань та сексуальної експлуатації» вік сексуальної згоди, виникає необхідність проаналізувати проблеми врегулю- вання добровільних статевих відносин між неповнолітніми за кримінальним законодавством України.

\section{Виклад основного матеріалу}

Законом України від 14 березня 2018 «Про внесення змін до Кримінального кодексу України щодо захисту дітей від сексуальних зловживань та сексуальної експлуатації» було змінено редакції статей 155 та 156 КК України. Зокрема, законом запропонована нова редакція статті 155 КК України. У частині першій статті законодавець змінив оціночне поняття «статева зрілість» на конкретний вік - 16 років, а також закріпив, що кримінальній відповідальності підлягають лише повнолітні особи за вчинення природних або неприродних статевих зносини. У частині другій статті перелік спеціальних суб'єктів злочину замінено загальним поняттям «близькі родичі або члени сім'і». Також статтю доповнено приміткою, яка відсилає до іншого нормативного акту. Змін у статті 156 набагато менше - у частині другій статті, за аналогією зі змінами у ч. 2 ст. 155 КК України, перелік спеціальних суб'єктів злочину замінено загальним поняттям «близькі родичі або члени сім'і».

Фактично вказаними змінами законодавець виконав вимоги ст. 18 Конвенції Ради Европи про захист дітей від сексуальної експлуатації та сексуального насильства. Статтею 18 Конвенції Ради Европи про захист дітей від сексуальної експлуатації та сексуального насильства закріплена пропозиція країнам-учасникам визначити вік, до досягнення якого заборонені статеві відносини 3 дитиною навіть за добровільної згоди останньої. Також положення ст. 18 Конвенції вказує, що вказані діяння з дитиною є кримінально караними виключно для повнолітніх осіб, тобто дія ст. 18 Конвенції не поширюється на врегулювання статевих стосунків між неповнолітніми, якщо ці відносини будуються на взаємній згоді неповнолітніх. Тобто фактично ст. 18 Конвенції встановлено відповідальність дорослих осіб перед дітьми.

у переважній більшості розвинених країн встановлено вік сексуальної згоди. 
Так, за законодавством Іспанії вік сексуальної згоди становить 13 років. 14 років - у Австрії, Естонії та Хорватії. 15 років Франція, Данія, Греція, Ісландія, Македонія, Молдова, Чехія, Швеція, Словаччина, Словенія, Монако, Польща, Румунія. 16 років - в найбільшій кількості країн, це Великобританія, Ізраїль, Канада, Аитва, Білорусь, Аатвія, Нідерланди, Таджикистан та інші. В деяких країнах, як от в Ірландії та на Кіпрі, вік сексуальної згоди досягає 17 років, на Мальті - 18 років.

Що стосується України, то вважаємо, що однозначного віку сексуальної згоди у КК України не закріплено. Доречно погодитися із думкою О.О. Дудорова та К.П. Задої, які проводячи дослідження концепту «вік сексуальної згоди» $[1,2]$, дійшли до висновку про те, що нинішня редакція Розділу IV КК України закріплює два «віки сексуальної згоди» [2, с. 86]. Так, вчені вказують, що частини четверті статей 152 і 153 КК України, викладені у редакції Закону України від 6 грудня 2017 р. «Про внесення змін до Кримінального та Кримінального процесуального кодексів України з метою реалізації положень Конвенції Ради Европи про запобігання насильству стосовно жінок і домашньому насильству та боротьбу 3 цими явищами», передбачаючи відповідальність за вчинення дій сексуального характеру щодо особи, яка не досягла чотирнадцяти років, незалежно від іiі добровільної згоди, та означають втілення у правову систему України європейського концепту «вік сексуальної згоди», у межах якого виключається виправдання винуватим своїх дій із посиланням на згоду потерпілої особи, яка не досягла певного віку. Щоправда, те саме можна сказати про викладену в редакції Закону України від 14 березня 2018 р. «Про внесення змін до Кримінального кодексу України щодо захисту дітей від сексуальних зловживань та сексуальної експлуатації» ст. 155 КК України, в якій своєрідним критерієм (показником) статевої недоторканності особи визначений вже не 14-річний, а 16-річний вік. При цьому, якщо Закон від 6 грудня 2017 р. був прийнятий 3 метою імплементації Стамбульської конвенції, в якій проблема «віку сек- суальної згоди» прямого (текстуального) відображення не знайшла, то ухвалення Закону від 14 березня 2018 р. видавалось за виконання Лансаротської конвенції, пункт а) ч. 1 ст. 18 якої зобов’ язує країни-учасниці визначити вік, до досягнення якого забороняється займатися діяльністю сексуального характеру з дитиною [1, с. 125-126].

Також наслідком майже одночасної імплементації у кримінальне законодавство правових норм, двох не до кінця узгоджених між собою Конвенцій є те, що законодавець не врегулював добровільні статеві відносини між неповнолітніми.

Приймаючи редакцію частин четвертих ст. 152 та 153 КК України, законодавець переслідував наміри на законодавчому рівні закріпити однозначне положення, 3 приводу того, що у разі вчинення дій сексуального характеру відносно особи молодшої 14 років, такі дії у будь-якому без виключення випадку будуть визнаватися відповідним насильницьким статевим злочином. У той же час законодавець ніяким чином не врегульовує добровільні статеві відносини між неповнолітніми. Так, згідно з ч. 2 ст. 22 КК України суб'єктом згвалтування чи сексуального насилля є особа, яка досягла 14 років, і таким чином, наприклад, чотирнадцятирічний юнак, який разом 3 тринадцятирічною дівчиною добровільно пізнають статеве життя, в силу ч. 4 ст. 152 чи 153 КК України підлягає кримінальній відповідальності за згвалтування чи сексуальне насилля. Санкції статей 152 та 153 КК України передбачають позбавлення волі на строк від десяти та від п'яти років відповідно. Можемо припустити, що законодавець, приймаючи в такій редакції частину четверту статей 152 та 153 КК України, навіть не задумувався, що може виникнути описана ситуація, оскільки законодавцем не проводилося жодних досліджень 3 метою збору та уніфікації даних про статеве життя підлітків та його початок. О.О. Дудоров, проводячи дослідження «віку сексуальної згоди», зазначає, що, за даними соціологічних досліджень ще 15-річної давності, регулярним статевим життям живуть 13,6 \% підлітків у віці 15-18 років, 30,9 \% підлітків у віці 14-15 років і 9,7 \% підлітків у віці 13 


\section{Кримінальне право, кримінальний процес та криміналістика}

років. Більш свіжі показники нам на очі не потрапили, хоч, за інформацією інших авторів, «секс між підлітками у віці 12-14 років, хочемо ми того чи ні, стає звичайною справою» $[2$, с. 84$]$.

Одним із варіантів врегулювання описаної ситуації є внесення відповідних змін у частині застосування примусових заходів виховного характеру, а саме закріплення у відповідній частині статті положення про те, що у випадку встановлення факту добровільних статевих відносин, які мають ознаки злочинів, передбачених ст. 152 та 153 КК України між малолітніми особами чи неповнолітніми і малолітніми особами, то такі особи звільняються від покарання і до них (обох сторін) застосовуються заходи статевого виховання. Безумовно, закріплюючи такі зміни, необхідно також створити такі інституції, які будуть займатися статевим вихованням таких осіб, а також потрібно буде вирішити питання судимості такої категорії осіб.

Що стосується закріплення кримінальної відповідальності за добровільні статеві злочини виключно повнолітніх, то доводиться констатувати факт, що законодавець, вносячи зміни у статті 155 та 156 , також допустився помилки, яка викликає труднощі при врегулюванні статевих відносин між неповнолітніми у віці 14-18 років. Так, природні чи неприродні статеві зносини між неповнолітніми у віці від 14 до 18 років не визнаватимуться злочином, у той час як будь-які сексуальні дії не пов'язані із проникненням у тіло особи кваліфікуватимуться як злочин, передбачений ст. 156 КК України. Така прогалина викликана тим, що вносячи зміни до ст. 155 КК України в частині відповідальності за природні чи неприродні статеві зносини виключно повнолітніх осіб, законодавець чомусь не вніс аналогічні зміни у ст. 156 КК України, а отже, на сьогодні відповідальності за розбещення неповнолітніх, згідно зі ст. 22 КК України, підлягають особи, яким виповнилося 16 років. Вказаний факт, по меншій мірі, є нелогічним, оскільки існує суттева різниця між статевими зносинами у природній чи неприродній формі та діями сексуального характеру, які із статевим проникненням у тіло не пов'язані. Для вирішення зазначеної проблеми у статтю 156 КК України необхідно внести зміни за аналогією зі ст. 155 КК України.

Враховуючи той факт, що внесення змін у статті 152-156 КК України є намаганням привести кримінальне законодавство України у відповідність з Европейськими стандартами, доцільно проаналізувати норми країн Европи, якими вони врегульовують добровільні статеві відносини між дітьми.

Так, у статті 13 частини другої, глави шостої КК Швеції вказано, що кримінальній відповідальності не підлягають особи, які вчинили сексуальні дії відносно дитини, якщо існує незначна різниця у віці та ступені розвитку між такими особами [3].

Згідно зі ст. 187 КК Швейцарії, кримінальній відповідальності за сексуальні дії відносно особи молодша 16 років не підлягають особи, з різницею у віці менше 3 років [4, с. 207]. Аналогічні норми містяться у законодавстві Австрії, Румунії, Італії [5].

Вік сексуальної згоди в ФРН - 14 років. Проте, добровільні статеві відносини з 14-15-річними особами дозволено лише, якщо партнер сам не старший 21 року. Якщо ж старшій за віком особі вже виповнився 21 рік, то за такі відносини старша особа підлягає кримінальній відповідальності. Сексуальні стосунки 3 16-17-річними дозволені у випадку надання останніми однозначної, усвідомленої згоди та якщо ці неповнолітні не перебувають у безпорадному стані[6].

У кримінальному законодавстві Норвегії також врегульовано добровільні статеві відносини між неповнолітніми. Так, параграфом 195 КК Норвегї̈ передбачено відповідальність за сексуальний контакт з дитиною, яка не досягла 14 років. У цьому ж параграфі, але в частині четвертій закріплене положення про мінімізацію покарання чи його відміну у випадку приблизно однакового віку неповнолітніх чи приблизно однакового розвитку. Аналогічні норми прописані також і у параграфі 196 КК Норвегії. Сдиною відмінністю між параграфом 195 та 196 є те, що параграфом 196 встановлено відповідальність за сексуальний контакт 3 дитиною віком до 16 років[7, с. 184-186]. 
У Кримінальному кодексі Голландії ч. 1 ст. 247 Книги 2, Розділу XIV встановлено кримінальну відповідальність за вчинення в тому числі і непристойних дій з особою, яка не досягла 16 років. У той же час у частині другій цієї ж статті зазначається, що у разі якщо особа, зазначена у частині першій, досягла дванадцятирічного віку, але не досягла шістнадцяти років, то кримінальне переслідування винної особи розпочинається виключно після подачі заяви потерпілою особою [8, с. 357-358]. Припускаємо, що таким чином законодавець врегульовує добровільні статеві відносини між неповнолітніми, а також між неповнолітніми та повнолітніми особами. Така побудова статті 247 КК Голландії, на нашу думку, мінімізує втручання у статеве життя неповнолітніх і в той же час дозволяє їх захищати шляхом подачі відповідних заяв.

Як бачимо, законодавці різних країн намагаються не втручатися у добровільні статеві відносини між неповнолітніми. «Кримінальне» врегулювання статевих відносин між неповнолітніми базується на побудові кримінальних норм таким чином щоб мінімізувати втручання у становлення і розвиток відносин, які виникають на межі неповноліття та дорослого життя. Особливої уваги заслуговують норми, які виключають відповідальність за добровільні статеві відносини між особами із законодавчо визначеною різницею у віці. Вважаємо, що означені норми потребують додаткового вивчення, шляхом проведення комплексного соціологічно-правового дослідження для імплементації у вітчизняне законодавство.

\section{Висновки}

Підсумовуючи викладене, зазначимо, що нинішня редакція статей не спроможна коректно врегулювати добровільні статеві відносини між неповнолітніми. Нинішня редакція Розділу IV КК України не дозволяє однозначно визначити «вік сексуальної згоди», що, у свою чергу, може бути використано на свою користь особами, які посягають на статеву недоторканість дітей, оскільки нинішня редакція ст. 156 КК України суперечить положенням Конвенції Ради Европи про захист дітей від сексуаль- ної експлуатації та сексуального насильства в частині кримінальної караності будь-яких статевих відносин виключно повнолітньої особи $з$ неповнолітньою особою за добровільної згоди останньої. Для приведення українського законодавства у відповідність 3 міжнародними стандартами у частині кримінальної відповідальності за статеві злочини повнолітніх перед неповнолітніми, також для врегулювання статевих відносин між неповнолітніми необхідно, для початку, внести зміни у ст. 156 за аналогією зі ст. 155 - встановити відповідальність за розпусні дії виключно повнолітніх осіб. Також необхідно провести комплексне соціологічно-правове дослідження з приводу статевих відносин неповнолітніх. Проведене дослідження дозволить чітко усвідомлювати проблематику статевих відносин між неповнолітніми та дасть можливість розробити соціальні та правові механізми направлені як на врегулювання статевих відносин між неповнолітніми, так і на створення інституцій, які будуть забезпечувати формування нормальних, 3 точки зору моральності, статевих відносин, відносин у сім'і, відносин, які базуватимуться на засадах добровільності та взаємоповаги.

Оскільки в рамках дослідження неможливо розкрити всі проблемні аспекти внесених у КК України змін, ми акцентували увагу лише на таких, які потребують, на нашу думку, якнайскорішого вирішення.

\section{入ітература}

1. Дудоров О.О. Задоя К.П. Конвенційний концепт «вік сексуальної згоди» у Кримінальному кодексі України: сучасний стан і перспективи / О.О. Дудоров, К.П. Задоя // Вісник кримінального судочинства. 2019. - № 1. - С. 123-134.

2. Дудоров О.О. Задоя К.П. «Вік сексуальної згоди» у міжнародному праві, кримінально-правовій доктрині та кримінальному кодексі України / О.О. Дудоров, К.П. Задоя // Вісник Ауганського державного університету внутрішніх справ імені Е. О. Дідоренка. - 2019. - Вип. 1. - С. 75-94.

3. Уголовный кодекс Швеции. Принят в 1962 году. [Әлектронный ресурс]. Режим доступа: http:// www.sweden4rus.nu/ 


\section{Кримінальне право, кримінальний процес та криміналістика}

rus/info/juridisk /ugolovnyj_kodeks_shvecii/. - Дата доступу: 28.03.2020.

4. Уголовный кодекс Швейцарии / Научное редактирование, предисловие и перевод с немецкого канд юрид наук А В Ceребренниковой - СПб Издательство «Юридический центр Пресс», $2002-350$ с.

5. Возраст сексуального согласия в Европе [Электронный ресурс]. - Режим доступа: https://ru.wikipedia.org/wiki/Boзраст сексуального_согласия_в_Европе/. - Дата доступу: 28.03.2020.

6. Що вважають сексуальним злочином в Німеччині? Що можна, що не можна? [Электронный ресурс]. - Режим доступа: http://cripo.com.ua/processes/?p=250267/. Дата доступу: 28.03.2020.

7. Уголовное законодательство Норвегии / Науч. ред. и вступ. статья докт. юрид. наук, профессора Ю. В. Голика; перевод с норвежского А.В. Жмени. - СПб.: Издательство «Юридический центр Пресс», 2003. - 375 c.

8. Уголовный кодекс Голландии / Науч. ред. докт. юрид. наук, заслуженный деятель науки РФ, проф. Б.В. Волженкин, пер. с англ. И.В. Мироновой. 2-е изд. СПб.: Издательство «Юридический центр Пресс», 2001. - 510с.
In the article, based on the analysis of theoretical developments in criminal law and current provisions of Section IV of the Special Part of the Criminal Code of Ukraine, an attempt is made to analyze the age of sexual consent and problematic issues of voluntary sexual relations between minors. In particular, the article notes that due to the almost simultaneous implementation in the criminal legislation of Ukraine of legal norms, two incompletely agreed Conventions, that the legislator does not regulate voluntary sexual relations between minors. In enshrining the provisions on criminal liability for voluntary sexual intercourse exclusively of adults, the legislator, by amending Articles 155 and 156, also made a mistake that causes difficulties in regulating sexual relations between minors aged 14-18. Thus, natural or unnatural sexual intercourse between minors between the ages of 14 and 18 will not be considered a crime, while any sexual acts not related to sexual penetration into the body of such a person will be classified as a crime under Art. 156 of the Criminal Code of Ukraine. The necessity of making changes to Art. 156 of the Criminal Code of Ukraine by analogy with Art. 155 of the Criminal Code of Ukraine.

In an attempt to resolve the issue of the settlement of voluntary sexual relations between minors, the criminal legislation of some countries was analyzed, which is aimed at the settlement of such relations both between minors and between minors and adults. It is emphasized that foreign legislators try to minimize interference in the voluntary sexual relations of minors by enshrining in criminal law age or other factors that allow such relations between minors and between minors and adults under a certain age. Emphasis is also placed on the norms that can be implemented in the criminal legislation of Ukraine after their additional study.

Conclusions were also made on the impossibility of unambiguously determining the age of sexual consent, as well as conclusions on the need for a comprehensive study of the issue of voluntary sexual relations between minors.

Key words: rape, sexual violence, sexual intercourse, debauchery of minors, lewd acts, coercion to have sexual intercourse, age of sexual consent, regulation of sexual relations, sexual crimes. 